\title{
Quantitative studies on the enzymatic hydrolysis of milk proteins brought about by cardosins precipitated by ammonium sulfate
}

\author{
Rui M. Barros, Carla A. Ferreira, Sofia V. Silva, F. Xavier Malcata* \\ Escola Superior de Biotecnologia, Universidade Católica Portuguesa, Rua Dr. António Bernardino de Almeida, P-4200-072 Porto, Portugal
}

Keywords: Dairy foods; Plant rennet; Proteases; Whey proteins

\begin{abstract}
Hydrolysis of whey proteins may produce peptide mixtures with better functional properties than the original protein mixture, viz. higher solubilites and lower allergenic effects. Cynara cardunculus is a wild plant that possesses (aspartic) proteases in its flower cells; those enzymes exhibit general proteolytic and specific milk clotting activities, which are rather useful in traditional cheesemaking. This study was thus aimed at characterizing the enzymatic action of crude extracts of said plant after preliminary purification by salting out with ammonium sulfate at two different concentration levels, viz. $30 \%$ and $70 \%$ saturation. The coagulant activity on milk, and the proteolytic activity using casein and azocasein as substrates, of the crude extract and of each precipitated fraction were measured at $37^{\circ} \mathrm{C}$ and $\mathrm{pH} 5.2$. The profile of hydrolysis of the major whey proteins, i.e. $\alpha$-lactalbumin $(\alpha$-La), $\beta$-lactoglobulin $(\beta$-Lg) and bovine serum albumin (BSA) was characterized by gel permeation chromatography and polyacrylamide gel electrophoresis (PAGE) in the presence of sodium dodecyl sulfate. The $30 \%$ and $70 \%$ saturation fractions exhibited lower coagulant and proteolytic specific activities than the crude extract. However, the relative ratio of coagulant to proteolytic activity, which is a useful indicator of appropriateness for cheesemaking, was higher for the partially purified fractions. The extents of hydrolysis of whey proteins brought about by the partially purified extracts were above those by their crude counterpart, but qualitative hydrolysis patterns were essentially identical to each other; by $24 \mathrm{~h}, \alpha$-La was substantially depleted, whereas $\beta$-Lg was very poorly hydrolyzed and BSA was only slightly hydrolyzed. The native proteins were converted to lower and lower molecular weight peptides. (C) 2001 Elsevier Science Inc. All rights reserved.
\end{abstract}

\section{Introduction}

Whey, a by-product of the cheese industry, has for long been considered as a waste product and looked upon seriously by environmentalists owing to its high polluting power. The main whey proteins are $\beta$-lactoglobulin, $\beta$ - $\mathrm{Lg}$ (ca. 50\%), $\alpha$-lactalbumin, $\alpha$-La (ca. 19\%), and bovine serum albumin, BSA (ca. 5\%) (Cayot et al., 1995). Hydrolysis of these proteins produces peptide mixtures with higher solubilities (Chobert et al., 1988), as well as better foaming characteristics, depending on the degree of hydrolysis (Adler et al., 1986); furthermore, the resulting peptides are more easily assimilated by microorganisms (Moneton et al., 1986), which obviously speeds up fermentation processes (Tchorbanov et al., 1988).

Aspartic proteases (EC 3.4.23) make up a family of

\footnotetext{
* Corresponding author.

E-mail address: xmalcata@esb.ucp.pt (F.X. Malcata).
}

enzymes that are widely distributed in animals, plants and microorganisms. In particular, the flowers of Cynara cardunculus have two aspartic proteases, viz. cardosin A and cardosin B; these enzymes are characterized by different amino acid sequences, and are thus probably the result of transcription of two distinct genes; each cardosin consists of two subunits, with apparent molecular weights $31 \mathrm{kDa}$ and $15 \mathrm{kDa}$ for cardosin A, and $34 \mathrm{kDa}$ and $14 \mathrm{kDa}$ for cardosin B (Veríssimo et al., 1995). The relative proportion of these proteinases depends on the cultivar in question, the part of the flower and the degree of maturation; in fresh flowers, the typical amount of cardosin B is $c a .25 \%$ of the total protein (Veríssimo et al., 1995). Interestingly, the dried flowers of C. cardunculus have for ages been successfully employed in Portugal and border regions of Spain as rennet for ewe's milk cheesemaking.

Rational use of these plant enzymes is somewhat difficult: first, the crude extract may contain several other compounds (including non-proteolytic enzymes), that will in principle promote occurrence of extraneous reactions; and 
second, such other enzymes may interfere with normal enzyme assays, thus introducing gross under- or over estimation of activity. Under the first type of problem, the high content of phenolic compounds is worth of notice, because they are easily oxidized (mainly under the influence of endogenous phenoloxidases) to form pigments; these pigments attach to proteins including native enzymes, and some do actually bind covalently thus leading to inactivation of those enzymes. Salting out of proteins is a widely used technique in enzyme purification, which takes advantage of the desolvation effect caused by high concentrations of salts. This phenomenon is appropriate not so much for fractionation of proteins, but mainly concentration of them, and is as well useful for removal of some contaminants.

The objective of the present study was two fold: (i) to optimize the extraction and purification of cardosins using ammonium sulfate as additive; and (ii) to characterize the action of the partially purified enzyme extracts on the profile of hydrolysis of the major whey proteins, i.e. $\alpha$-La, $\beta$ - $\mathrm{Lg}$ and BSA (qualitative action), and on the extent of caseinolysis (quantitative action). In order to maximize the information generated pertaining to the action of these enzymes, high resolution analytical techniques, e.g. Fast Protein Liquid Chromatography (FPLC) and electrophoresis (PAGE), were utilized.

\section{Materials and methods}

\subsection{Substrates}

A commercial whey protein concentrate (WPC), with an average protein content of $11 \%(\mathrm{w} / \mathrm{w})$, was purchased from Sigma (St. Louis MO, USA), and used as standard substrate.

\subsection{Chemicals}

Azocasein, sodium dodecyl sulfate (SDS), $\beta$-mercaptoethanol, ammonium persulfate, TEMED $\left(\mathrm{N}^{\prime} \mathrm{N}^{\prime} \mathrm{N}^{\prime} \mathrm{N}\right.$-tetramethylethylenediamine), and molecular weight standards for Phast ${ }^{\circledR}$ electrophoresis (BSA-66 kDa, ovalbumin-45 kDa, glyceraldehyde-3-phosphate dehydrogenase-36 kDa, carbonic anhydrase- $29 \mathrm{kDa}$, trypsinogen- $24 \mathrm{kDa}$, trypsin inhibitor-20 kDa and $\alpha$-La-14.2 kDa) were all purchased from Sigma; trichloroacetic acid (TCA), sodium dihydrogen phosphate monohydrate, disodium hydrogen phosphate dihydrate, citric acid monohydrate and extra pure sodium azide were obtained from Merck (Darmstadt, Germany). High density minigels, PhastGel SDS buffer strips, low molecular weight standards for SDS-PAGE (phosphorylase B-94 kDa, BSA-67 kDa, ovalbumin-43 kDa, carbonic anhydrase-30 kDa, soybean trypsin inhibitor-20.1 kDa and $\alpha$-La-14.4 kDa) and molecular weight standards for FPLC (aldolase-158 kDa, BSA-67 kDa, ovalbumin-43 kDa, $\beta$-Lg-36 kDa, $\alpha$-La-14.4 kDa and ribonuclease-13.7 kDa) were all purchased from Pharmacia LKB Biotechnology
(Uppsala, Sweden). Filter paper $(0.22 \mu \mathrm{m})$ was purchased from Nalgene (New York NY, USA), whereas nonsterile filters $(0.45 \mu \mathrm{m})$ were purchased from Nucleopore (Cambridge MA, USA). Tap water was purified in a Milli-Q Plus 185 system (Molsheim, France) to a final conductivity of $c a$. $18.2 \mathrm{M} \Omega . \mathrm{cm}^{-1}$. The chemicals used were all analytical grade or better, and were employed without further purification.

\subsection{Enzymes}

A crude blend of cardosins A and B, as they occur in nature after aqueous extraction from flowers of $C$. cardunculus, was employed as catalyst. The crude enzyme extract was prepared by macerating $c a .7 \mathrm{~g}$ of stylets and stigmæ of dried flowers of $C$. cardunculus in $70 \mathrm{ml}$ of $100 \mathrm{mM}$ sodium citrate buffer (pH 3.0), as described by Faro (1991). Two enzyme preparations were then obtained from the supernatant via a two-step purification procedure. The supernatant was first precipitated using ammonium sulfate up to $30 \%$ saturation, kept at $4^{\circ} \mathrm{C}$ for $30 \mathrm{~min}$, and then centrifuged (at $16300 \mathrm{~g}$ and $4^{\circ} \mathrm{C}$, for $10 \mathrm{~min}$ ) using a Model Refrigerated RC-5C from Sorvall Instruments (Newtown CT, USA). To the new supernatant more ammonium sulfate was then added up to $70 \%$ saturation. After a further $30 \mathrm{~min}$, the solution was centrifuged under the same conditions. Both precipitates were redissolved in water up to approximately twice the volume of the pellet, and dialyzed for $48 \mathrm{~h}$ at $4^{\circ} \mathrm{C}$ against a large volume of deionized water (to remove ammonium sulfate and citrate) using dialysis tubing with MW cutoff of $10 \mathrm{kDa}$ (Sigma), and finally lyophilyzed. Determination of the total protein content of the enzyme extract and of the partially purified enzymes took advantage of the Micro Protein determination kit No. A-690 (Sigma).

\subsection{Analytical equipment}

All spectrophotometric readings were carried out using quartz cuvettes in an UV-VIS spectrophotometer from Shimadzu (Kyoto, Japan). The enzyme aqueous extract was lyophilyzed in a CHRIST ALPHA 1-4 freeze-dryer, from Braun Biotech (Braunschweig, Germany). High density electrophoretic gels were run using a PhastSystem unit (from Pharmacia LKB Biotechnology). SDS-PAGE was performed in a Protean II xi vertical slab-gel unit from Bio-Rad (Watford, UK) coupled with a model 1000/500 power supply also from Bio-Rad, and a refrigerated water bath from Julabo Labortechnik (Seelbach, Germany). All electrophoresis gels were scanned in a GS-700 Imaging Densitometer from Bio-Rad (Hercules CA, USA) using the Molecular Analyst software (Si 1.4) also from Bio-Rad. The FPLC system (Pharmacia LKB Biotechnology) consisted of two P-500 positive displacement pumps, an electrically powered MV-7 motorized valve, a gel filtration column pre-packed with Superose 12 HR 10/30, and an UVII singlepath spectrophotometer monitor. Samples were previously 
passed through a $0.45 \mu \mathrm{m}$ filter and then injected through a $100 \mu$ l-loop.

\subsection{Proteolysis assay}

The enzyme-mediated hydrolysis was started with the addition of suitable quantities of enzyme extract so as to get the desired constant ratio of enzyme to substrate (WPC), on a protein weight basis, viz. 2/200 (w/w). The reactions were performed batchwise, in $50 \mathrm{ml}$ of $100 \mathrm{mM}$ citrate buffer $(\mathrm{pH}$ $5.2,1 \mathrm{~g}_{\mathrm{WPC}} / \mathrm{mL}$ ) at $37^{\circ} \mathrm{C}$, in a water bath equipped with an orbital shaker set at $100 \mathrm{rpm}$. Samples were withdrawn in duplicate at selected time intervals, and duly prepared both for FPLC and SDS-PAGE analyses.

The proteolytic activity was evaluated using two alternative methods. The first was a modification of the method proposed by Tomarelli et al. (1949), which involves digestion of azocasein (obtained from a casein chromophore containing a dinitrogenated arylamine) and quantification of the proteolytic activity based on the peptides released as monitored by absorbance at $440 \mathrm{~nm}$. In this case, the lyophilyzed crude extract and the two fractions precipitated therefrom were dissolved in $0.1 \mathrm{M}$ phosphate buffer ( $\mathrm{pH} \mathrm{6.0)}$ to produce the enzyme solution. This enzyme solution $(0.01 \mathrm{~g} / \mathrm{mL})$ was mixed $(0.01 \mathrm{ml})$ with $0.5 \mathrm{ml}$ of $2 \%(\mathrm{w} / \mathrm{v})$ azocasein and incubated at $25^{\circ} \mathrm{C}$ for $10 \mathrm{~min}$; the reaction was then quenched by adding $0.5 \mathrm{ml}$ of cold $5 \%(\mathrm{w} / \mathrm{v})$ TCA. Unhydrolyzed proteins were then removed by centrifugation (using a Model Universal 32-refrigerator from Hettich, Tuttlingen, Germany) at $10300 \mathrm{~g}$ and $4{ }^{\circ} \mathrm{C}$ for $10 \mathrm{~min}$. To intensify the azo-associated color, $1 \mathrm{ml}$ of the supernatant was mixed with $1 \mathrm{ml}$ of $0.5 \mathrm{M} \mathrm{NaOH}$. A blank was prepared in a similar fashion, but with the addition of TCA before addition of enzyme.

The second procedure used a modification of the method by Kunitz (1947), which involves hydrolysis of bovine casein itself. Aliquots $(1.9 \mathrm{ml})$ of $2 \%(\mathrm{w} / \mathrm{v})$ casein in a $0.1 \mathrm{M}$ phosphate buffer ( $\mathrm{pH} 6.5$ ) were pre-incubated at $30^{\circ} \mathrm{C}$ for 5 min, in a water bath equipped with an orbital shaker set at $100 \mathrm{rpm}$. The reaction was initiated by adding $0.1 \mathrm{ml}$ of enzyme solution $(0.01 \mathrm{~g} / \mathrm{mL})$, prepared as described above, but using 0.1 M phosphate buffer ( $\mathrm{pH}$ 6.5). Samples (0.45 $\mathrm{ml}$ ) were withdrawn in triplicate at selected time intervals, and the reaction was quenched by adding $0.9 \mathrm{ml}$ of cold $5 \%(\mathrm{w} / \mathrm{v}) \mathrm{TCA}$. Unhydrolyzed proteins were then removed by centrifugation, at $14900 \mathrm{~g}$ and $4^{\circ} \mathrm{C}$ for $10 \mathrm{~min}$. A blank was prepared in the same manner but with addition of TCA before the enzyme was added. The enzyme activity was based on the amount of peptides released, as monitored by absorbance at $280 \mathrm{~nm}$. For both methods, assays were performed in triplicate.

\subsection{Coagulation assay}

The clotting activity was determined using the procedure described in IDF-157 (1992). The lyophilyzed crude extract
(0.05 g/mL) was dissolved in $10 \mathrm{mM} \mathrm{CaCl}_{2}(\mathrm{pH} \mathrm{6.5)}$; the clotting time was measured using $0.2 \mathrm{ml}$ of each enzyme solution, which was mixed with $2 \mathrm{ml}$ of reconstituted milk. One rennet unit (RU) was defined as the amount of crude extract needed to coagulate $10 \mathrm{ml}$ of reconstituted low-heat skim milk powder (NILAC ${ }^{\mathrm{TM}}$, from NIZO, Ede, The Netherlands) at $30^{\circ} \mathrm{C}$ in $100 \mathrm{~s}$ (Berridge, 1945). The assay was carried out in triplicate.

\subsection{Statistical Analysis}

The data were assessed by analysis of variance (ANOVA) using the Excel ${ }^{\mathrm{TM}}$ software from Windows $95 \mathrm{v}$. 7.0; the results were considered significant if the associated $P$ value was below 0.05 ; Student's $t$-tests were employed for comparison of means.

\subsection{Electrophoretic characterization}

High density gel electrophoresis was performed with a PhastSystem unit and appropriate minigels $(50 \mathrm{~mm}$ high $\mathrm{x}$ $43 \mathrm{~mm}$ wide $\times 0.45 \mathrm{~mm}$ thick). For the preparation of samples, pre-determined amounts (ca. $0.01 \mathrm{~g}$ ) of each (partly purified) cardosin extract were placed in separate eppendorf vials, and $100 \mu \mathrm{l}$ of $10 \%(\mathrm{w} / \mathrm{v})$ SDS was added (to eliminate shape and charge effects). The vials were subsequently heated at $90^{\circ} \mathrm{C}$ for $\mathrm{ca} .10 \mathrm{~min}$ in a heating block, and then cooled to near room temperature. Approximately 4 $\mu l$ of solution of denatured sample (or markers, as appropriate) were applied onto the gel surface. After electrical resolution of the sample proteins, the gels were transferred to the development section of the PhastSystem unit, and duly stained with Coomassie Blue R 250.

For the preparation of samples for SDS-PAGE, $500 \mu \mathrm{l}$ of the reaction medium (withdrawn at regular time intervals) was poured into eppendorf vials, into which $100 \mu \mathrm{l}$ of $10 \%(w / v)$ SDS was latter added. The vials were subsequently heated at $90^{\circ} \mathrm{C}$ for $c a .10 \mathrm{~min}$ in a boiling water bath, cooled to near room temperature and centrifuged at $10300 \mathrm{~g}$ and $4^{\circ} \mathrm{C}$ for $10 \mathrm{~min}$. A solution containing SDS, $\beta$-mercaptoethanol, sucrose and bromophenol blue was added to the supernatant of said samples, which were incubated in a heating block at $90^{\circ} \mathrm{C}$ for $\mathrm{ca} .5 \mathrm{~min}$. The $15 \%$ (w/v) polyacrylamide gel slabs $(20 \mathrm{~cm}$ high $\times 16 \mathrm{~cm}$ wide $\mathrm{x} 0.75 \mathrm{~mm}$ thick), at $\mathrm{pH} 8.6$ and containing $0.1 \%(\mathrm{w} / \mathrm{v})$ SDS, were prepared and run for $10 \mathrm{~h}$ using the discontinuous buffer system of Laemmli (1970) at constant voltage $(100 \mathrm{~V})$, constant current $(70 \mathrm{~mA})$ and constant temperature $\left(19^{\circ} \mathrm{C}\right)$; after this time, the gels were stained with Coomassie Blue R 250. Qualitative and quantitative analyses of the electrophoretograms produced were by densitometric scanning, using a green filter in a GS-700 imaging densitometer; the data were later subject to the Molecular Analyst ${ }^{\mathrm{TM}}$ software for image analysis. Each line was scanned twice. 


\subsection{Chromatographic characterization}

The reaction samples were assayed by gel permation in an FPLC system, according to the procedure described by Pintado and Malcata (1996). Aliquots $(1.5 \mathrm{ml})$ of the incubated solution were taken at $0,0.5,1,2,5,8,12$ and $24 \mathrm{~h}$, and the reaction therein was quenched by immersion in liquid nitrogen; said aliquots were stored at $-20^{\circ} \mathrm{C}$ until use. Prior to chromatographic analyses, each sample was passed through a $0.45 \mu \mathrm{m}$ filter (Nucleopore CA, USA), whereas the mobile phase was filtered through $0.22 \mu \mathrm{m}$ paper filter (Nalgene). Aliquots $(100 \mu \mathrm{l})$ were injected into the FPLC equipped with a Superose 12 column HR 10/30 (Pharmacia) and an UV-MII-detector (280 nm); the mobile phase was $150 \mathrm{mM} \mathrm{NaCl}$ in a $50 \mathrm{mM}$ aqueous phosphate buffer (pH 7.0), containing $0.2 \mathrm{~g} \mathrm{~L}^{-1} \mathrm{NaN}_{3}$ as preservative, at a flow rate of $0.4 \mathrm{ml} \mathrm{min}{ }^{-1}$ for $80 \mathrm{~min}$. The retention times of the peaks obtained were compared with those of a mixture of molecular weight standards. Quantitative calibration of the column, in terms of bovine whey proteins, was performed using various dilutions of an aqueous solution containing $4.10 \mathrm{mg} / \mathrm{mL}$ of $\alpha-\mathrm{Lg}, 9.10 \mathrm{mg} / \mathrm{mL}$ of $\alpha$-La, $6.80 \mathrm{mg} / \mathrm{mL}$ of BSA, $0.10 \mathrm{mg} / \mathrm{mL}$ of orotic acid and 0.020 $\mathrm{mg} / \mathrm{mL}$ of uric acid. The void volume of the column was previously determined using blue dextran (the retention time was ca. $19.5 \mathrm{~min}$ ). All analyses were carried out in duplicate.

\section{Results and discussion}

\subsection{Enzyme purification}

The initial step in purification of the proteases present in the crude aqueous extract of $C$. cardunculus was based on salting out of proteins at two different levels of ammonium sulfate. The protein concentration obtained was 92, 410 and $197 \mathrm{mg}_{\text {protein }} \mathrm{g}^{-1}$ in the lyophilyzed crude extract, and in the $30 \%$ and $70 \%$ saturation fractions, respectively. The associated SDS-PAGE electrophoretograms (Fig. 1) indicate that both precipitates were qualitatively similar, and in particular contained polypeptides with molecular weights of ca. 30 and 15, and of ca. 35 and $14 \mathrm{kDa}$, which correspond to the two subunits of cardosin A and B, respectively. The intensity of the band that is accounted for by cardosin A was higher in the $30 \%$ fraction than in the $70 \%$ one, whereas the other bands with similar mobilities in both fractions showed similar intensity as well. Furthermore, the fraction precipitated at $30 \%$ saturation exhibited two extra bands, characterized by molecular weights $20-26 \mathrm{kDa}$.

\subsection{Quantitative activity}

The coagulation activity in bovine milk, and the proteolytic activity on casein and azocasein of the two partially purified enzyme fractions are shown in Table 1. Although a

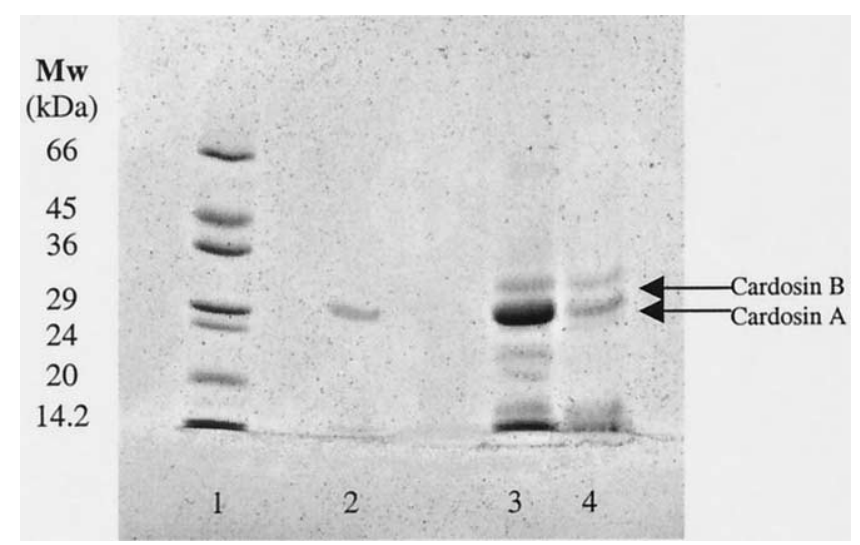

Fig. 1. High density electrophoretogram of the fractions obtained upon precipitation with ammonium sulfate. Lane 1: molecular weight (Mw) markers; lane 2: supernatant at $70 \%$ saturation; lane 3: fraction precipitated at $30 \%$ saturation; and lane 4: fraction precipitated at $70 \%$ saturation.

model system more representative of the whey proteins might be preferable, no data are available in the literature pertaining to cardosins acting on whey proteins, so critical discussion based on comparison with other works would be impossible. The clotting activity is related to the enzyme's capacity to cleave $\kappa$-casein at the Phe105-Met106 peptide bond, which is the starting point of enzymatic cheesemaking. According to Veríssimo (1995), cardosin B has a broader specificity than cardosin A, although they share the same preference for peptide bonds with hydrophobic side chains. The statistical analysis (ANOVA) show that there were significant differences between the coagulant activity obtained for the crude extract and for the two other fractions $(P<0.005)$. The data also show that precipitation produced a slight decrease on the coagulant activity in the first fractionation step ( $c a .13 \%$ ), but a higher decrease in the second fractionation step (ca. 28\%). The results also indicate that coagulation activity of the fractions at 30 and $70 \%$ saturation were significantly different $(P<0.001)$. This difference is confirmed by the lower intensity of the band corresponding to cardosin $\mathrm{A}$ in the $70 \%$ saturation fraction (Fig 1, lane 4) than in the $30 \%$ saturation one (Fig. 1, lane 3).

The data tabulated in Table 1 show that fractionation produces a decrease in the proteolytic activity relative to that of the crude extract. The higher decrease on proteolytic activity, ca. 88 and $84 \%$, occurred for fractionation at $30 \%$ saturation, when tested with casein and azocasein, respectively. In both cases, the percent variation was much higher for specific proteolytic activity than for specific coagulant activity. The lower values for the specific activity at $30 \%$ when compared with those at $70 \%$ saturation fractions are concomitant with the presence of two extra bands, coupled with an apparently higher relative amount of cardosin A than cardosin B (Fig. 1). The differences between the three cases studied for proteolytic activity, either tested with casein or azocasein, were significant $(P<0.0001)$.

The analysis of the relative ratio of clotting activity to 
Table 1

Enzymatic activity of ammonium sulfate-precipitated fractions, as compared with crude extract from $C$. cardunculus (thistle).

\begin{tabular}{|c|c|c|c|c|c|}
\hline \multicolumn{6}{|l|}{ Specific activity* } \\
\hline \multirow[t]{2}{*}{ Thistle } & \multirow{2}{*}{$\begin{array}{l}\text { Coagulant }(c) \\
(U / g)\end{array}$} & \multicolumn{2}{|l|}{ Proteolytic $(p)$} & \multicolumn{2}{|l|}{ Ratio $c / p$} \\
\hline & & $\begin{array}{l}\text { Casein } \\
\left(\Delta A_{280} / g / m i n\right)\end{array}$ & $\begin{array}{l}\text { Azocasein } \\
\left(\Delta A_{440} / g / m i n\right)\end{array}$ & $\begin{array}{l}\text { Casein } \\
\left(U * \min / \Delta A_{280}\right)\end{array}$ & $\begin{array}{l}\text { Azocasein } \\
\left(U^{*} \min / \Delta A_{440}\right)\end{array}$ \\
\hline Crude extract & $103.6 \pm 4.1$ & $16.4 \pm 1.3$ & $1.53 \pm 0.10$ & $5.34 \pm 0.72$ & $68 \pm 10$ \\
\hline $30 \%$ sat. fraction & $90.6 \pm 2.0$ & $2.00 \pm 0.14$ & $0.242 \pm 0.011$ & $45.3 \pm 6.6$ & $378 \pm 35$ \\
\hline $70 \%$ sat. fraction & $74.6 \pm 2.7$ & $4.85 \pm 0.21$ & $0.791 \pm 0.042$ & $15.3 \pm 1.7$ & $94 \pm 12$ \\
\hline
\end{tabular}

* Average values $\pm 95 \%$ confidence interval.

Note: $\Delta A_{280}$ - variation of absorbance at $280 \mathrm{~nm}$.

$\Delta A_{440}$ - variation of absorbance at $440 \mathrm{~nm}$.

proteolytic activity (c/p), which is an useful indicator of protease adequacy for use as coagulant in cheesemaking, is underlaid in Table 1. When all enzyme preparations were compared which each other, ANOVA revealed that there are significant differences $(P<0.0001)$ in said ratio. Ammonium sulfate fractionation produced an increase of this ratio relative to that in the crude extract: the highest increase occurred at $30 \%$ saturation, which produced a 7-fold increase when casein was used as substrate $(P<0.005)$ and a 6-fold increase when azocasein was used instead $(P<$ $0.001)$. At $70 \%$ saturation, the difference was also significant $(P<0.005)$ when comparison was made with the crude extract, but the rise of values for the $\mathrm{c} / \mathrm{p}$ ratio was slightly lower, viz. 1.4- and 2.4-fold increase for casein and azocasein as substrate, respectively. Finally, when the c/p ratios obtained at $30 \%$ and $70 \%$ saturation were compared, the differences were again significant $(P<0.005)$. According to these results, the enzyme fractionate obtained at $30 \%$ saturation possesses the best $\mathrm{c} / \mathrm{p}$ ratio for use as coagulant in cheesemaking; however, use in actual cheesemaking practice is worthy extra work for full validation of this statement.

\subsection{Qualitative activity}

The elution profile of the major whey proteins as incubation time elapses is shown in Fig. 2. The elution patterns are virtually identical, irrespective of preliminary precipitation of the crude extract with ammonium sulfate. These profiles reveal a decrease in concentration of $\alpha$-La, whereas the concentration of $\beta-\mathrm{Lg}$ remains unaltered with incubation time.

The time course of the enzyme-mediated hydrolysis of whey proteins, brought about by the two different fractions and by the crude extract, as assessed by SDS-PAGE is available in Figs. 3 and 4. The action of enzymes precipitated at $30 \%$ or $70 \%$ saturation on the main whey proteins was rather similar to that of the crude extract. In all cases studied, $\alpha$-La was never hydrolyzed in full, but it was possible to observe that the hydrolysis rate of $\alpha$-La was slightly lower by the $30 \%$ than by the $70 \%$ saturation fraction (Figs. 3a, 4a). This situation was also apparent
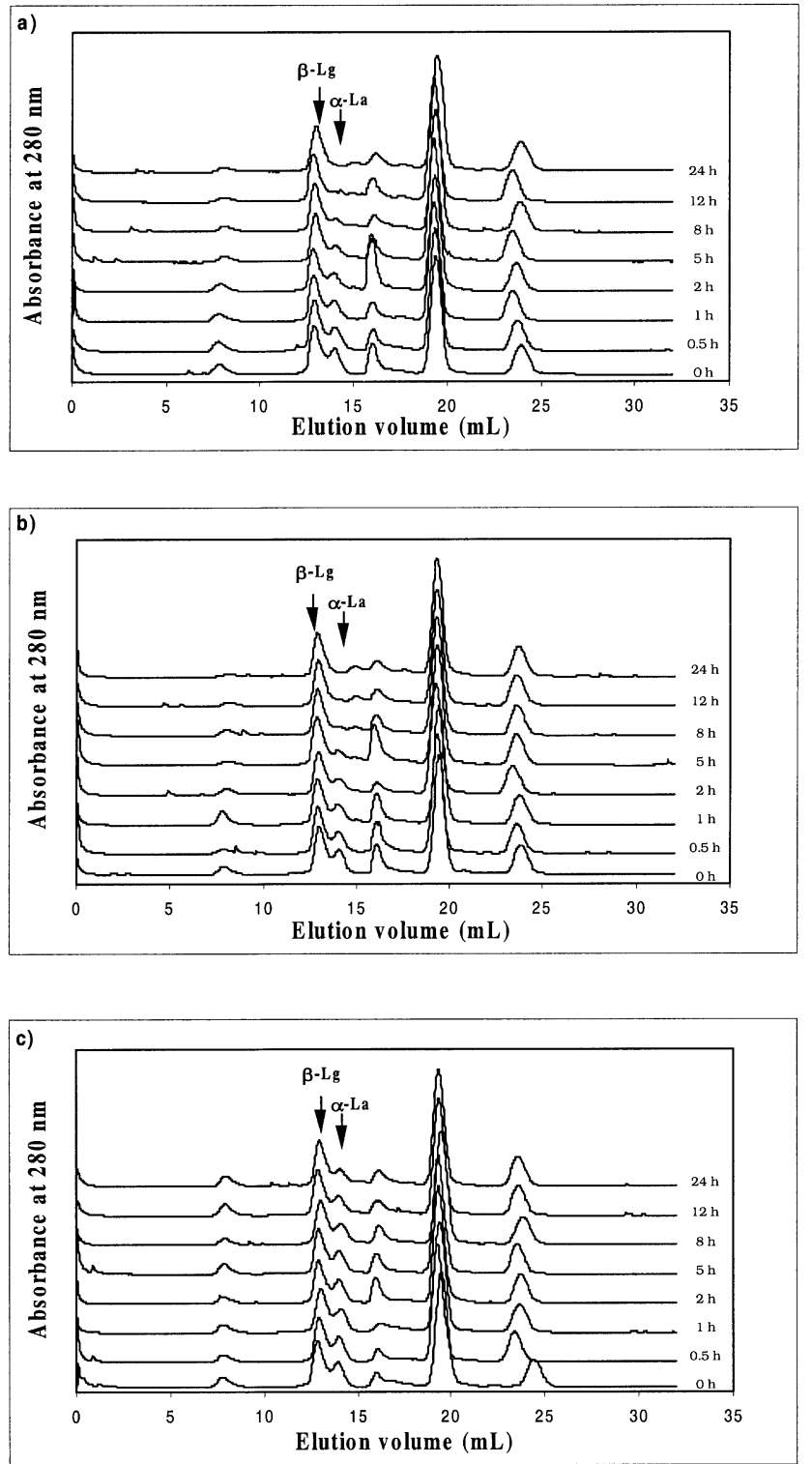

Fig. 2. FPLC profile of whey proteins after hydrolysis for $0,0.5,1,2,5,8$, 12 and $24 \mathrm{~h}$, effected by the fraction of crude extract precipitated at (a) $30 \%$ and (b) $70 \%$ saturation with ammonium sulfate, and by (c) the crude extract. 


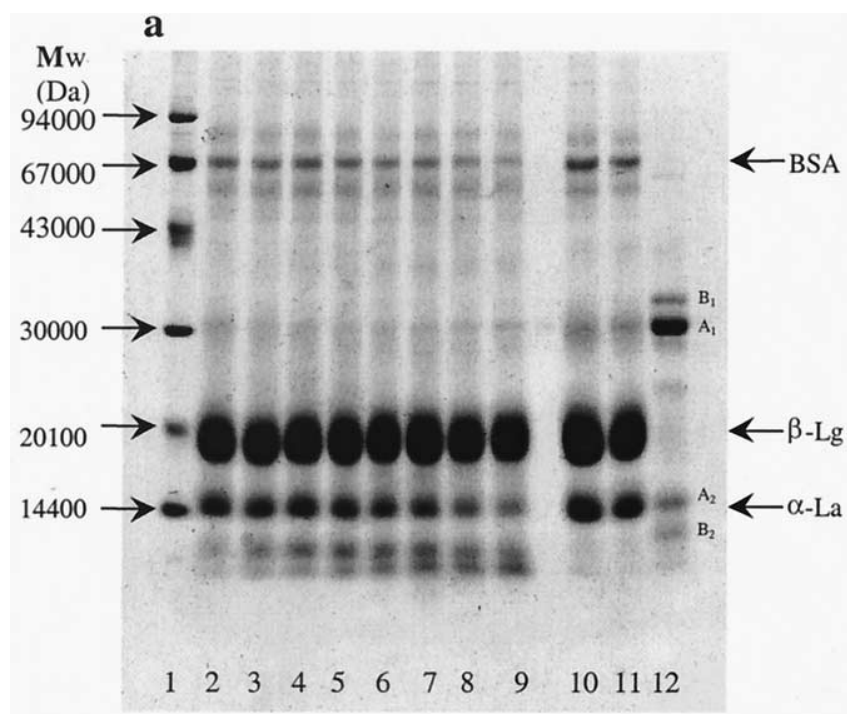

b

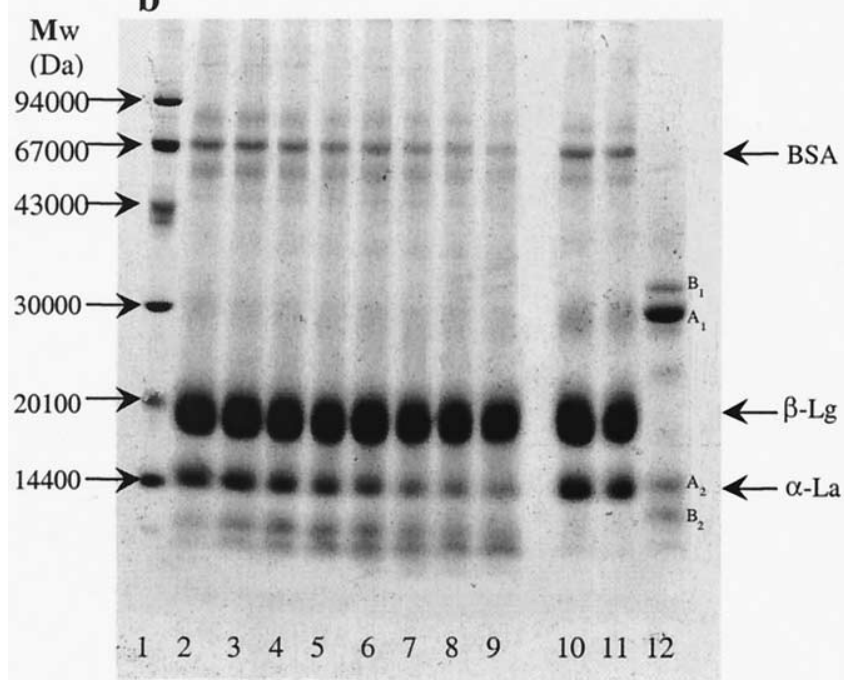

Fig. 3. SDS-PAGE electrophoretograms of the hydrolyzates produced by the fraction precipitated at $30 \%$ (a) and $70 \%$ (b) saturation with ammonium sulfate. Lane 1: molecular weight (Mw) markers; lane 2-9: samples withdrawn at $0,0.5,1,2,5,8,12$, and $24 \mathrm{~h}$ of incubation, respectively; lanes 10-11: control without enzyme, at 0 and $24 \mathrm{~h}$, respectively; and lane 12 : crude extract: cardosin $A$ (subunits $A_{1}$ and $A_{2}$ ) and cardosin $B$ (subunits $B_{1}$ and $\mathrm{B}_{2}$ ).

when the $30 \%$ and $70 \%$ saturation fractions were tested with casein and azocasein as substrates (see Table 1). Conversely, BSA was poorly hydrolyzed during the same time frame; finally, $\beta$-Lg remained essentially intact by $24 \mathrm{~h}$ of hydrolysis. In general, $\alpha$-La was hydrolyzed up to $90 \%$ within $24 \mathrm{~h}$, whereas BSA was hydrolyzed only to $65-70 \%$ (see Figs. 4a, 4c). These observations are a clue to the higher affinity of cardosins $\mathrm{A}$ and $\mathrm{B}$ for $\alpha$-La and, to a lesser extent, BSA. Cardosins are indeed known to cleave peptide bonds between amino acid residues with large hydrophobic
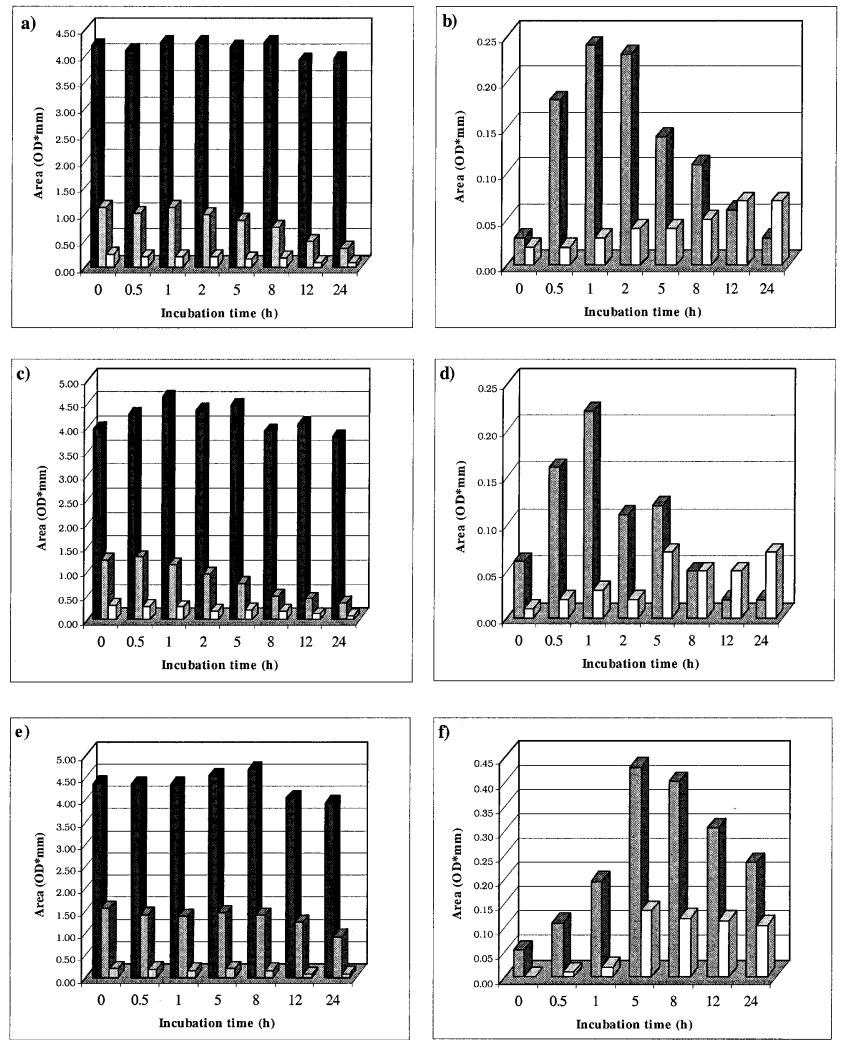

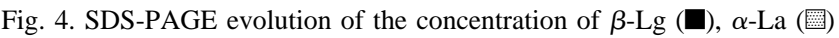
and $\operatorname{BSA}(\square)$ with incubation time, when acted upon by the fraction precipitated at (a) $30 \%$ saturation and at (c) $70 \%$ saturation with ammonium sulfate, and by (e) the crude extract; the two main peptides formed, with molecular weights $6 \mathrm{kDa}(\square)$ and $3 \mathrm{kDa}(\square)$, by the action of the fraction precipitated at (b) $30 \%$ saturation and at (d) $70 \%$ saturation, and by (f) the crude extract are also shown.

side chains, such as Phe and Leu (Webb, 1991); the threedimensional structure of native $\alpha$-La (Warme et al., 1974; Acharya et al., 1990) encompasses a large hydrophobic area on the surface of the protein.

The electrophoresis patterns of the enzyme-mediated hydrolysis of whey proteins produced via the action of the two distinct fractions were similar to each other (Fig. 3); the enzymes present in either fraction acted mainly on $\alpha$-La (as already discussed), which led to generation of medium- and low-molecular weight peptides (Fig. 4). The primary breakdown peptides accounted for two bands, with molecular weights between 3 and $6 \mathrm{kDa}$; as hydrolysis time elapsed, these peptides were gradually broken down to smaller ones (Fig. 3). In Figs. 4b and 4d, the band associated with the 6 kDa-fragment became thicker by $1 \mathrm{~h}$ and then gradually disappeared; conversely, the band associated with the 3 $\mathrm{kDa}$-fragment increased in intensity as hydrolysis time elapsed.

\section{Conclusions}

Precipitation with ammonium sulfate is an effective way to produce substantial amounts of active proteases from the 
flowers of $C$. cardunculus. Said precipitation produces a decrease of coagulant and proteolytic specific activities when azocasein or casein are used as substrate, but contributes to higher relative ratios of coagulant to proteolytic activities, which improves clotting capacity for actual cheesemaking. The casein and azocasein substrates correlate well with one another, so they can interchangeably be used in monitoring proteolytic activity. The major whey proteins were differently acted upon by the enzymes under consideration: $\alpha$-La was hydrolyzed to a higher extent than $\mathrm{BSA}$, and to a much higher extent than $\beta$ - $\mathrm{Lg}$ for the same incubation time.

\section{Acknowledgments}

Authors R.M.B and S.V.S. acknowledge funding by Fundação para a Ciência e Tecnologia (Portugal), via Ph.D. fellowships ref. PRAXIS XXI BD/16037/98 and PRAXIS XXI BD/18479/98, respectively.

\section{References}

[1] Cayot P, Lorient D. Food Proteins and Their Applications: Structurefunction Relationships of Whey Proteins. 1995;8:225-56.

[2] Chobert J, Bertrand-Hard C, Marie-Georgette N. Solubility and emulsifying properties of caseins and whey proteins modified enzymatically by trypsin. J Agric Food Chem 1988;36:88392.
[3] Adler-Nissen J. Enzymic Hydrolysis of Food Proteins. London, UK: Elsevier, 1986.

[4] Moneton P, Sarthou P, Le Goffic F. Transport and hydrolysis of peptides in Saccharomyces cerevisae. J Gen Microbiol 1986;132: 2147-53.

[5] Tchorbanov B, Lazarova G. Evaluation of protein hydrolysates using the fermentation activity of immobilized yeast cells. Biotechnol Appl Biochem 1988;10:301-4.

[6] Veríssimo P, Esteves C, Faro CJ, Pires EV. The vegetable rennet of Cynara cardunculus L. contains two proteinases with chymosin and pepsin-like specificities. Biotechnol Lett 1995;17:621-6.

[7] Tomarelli R, Charney M, Harding M. The use of azoalbumin as a substrate in the colorimetric determination of peptic and tryptic activity. J Lab Clin Med 1949;34:428-33.

[8] Kunitz M. Crystalline soybean trypsin inhibitor II. General properties. J Gen Physiol 1947;30:291-392.

[9] Anonymous. International Dairy Federation Standard 157. Bovine Rennets. Determination of total milk-clotting activity. Brussels, Belgium: International Dairy Federation, 1992.

[10] Berridge NJ. Some observations on the determination of activity of rennet. Analyst 1952;77:57-72.

[11] Laemmli UK. Cleavage of structural proteins during the assembly of the head of bacteriophage T4. Nature 1970;227:680-5.

[12] Pintado MME, Malcata FX. Effect of thermal treatment on the protein profile of whey from ovine and caprine milk throughout lactation. Int Dairy J 1996;6:497-518.

[13] ] Webb EC. In: Enzyme Nomenclature. NY, USA: Academic Press, 1992.

[14] Warme PK, Momany FA, Rumball SV, Tuttle RW, Scheraga HA. A computation of structures of homologous proteins: $\alpha$-lactalbumin from lysozyme. Biochemistry 1974;13:768-82.

[15] Acharya KR, Stuart DI, Phillips DC, Scheraga HA. A critical evaluation of the predicted, and X-ray structures of $\alpha$-lactalbumin. J Protein Chem 1990;9:549-63. 